ISSN 1678-3921

Journal homepage: www.embrapa.br/pab

For manuscript submission and journal contents, access: www.scielo.br/pab

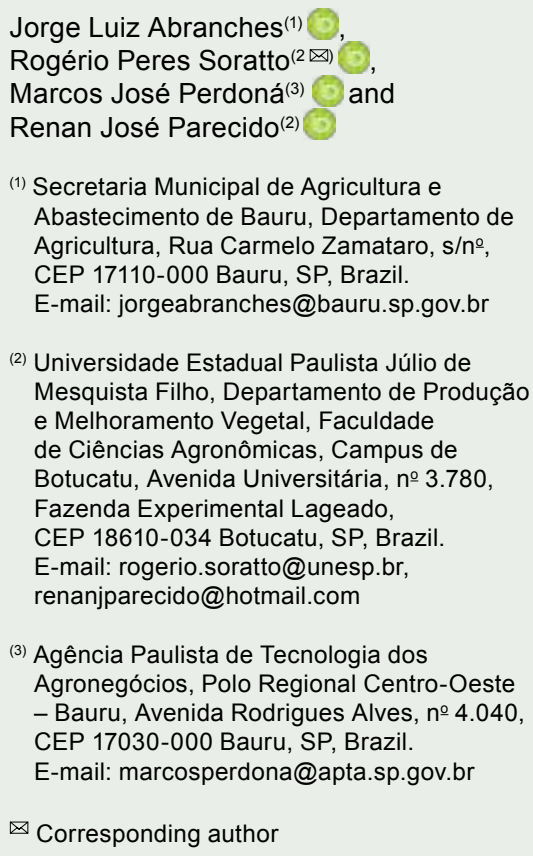

\section{Arabica coffee response to rates of coated and conventional urea in sandy soil}

\begin{abstract}
The objective of this work was to evaluate the growth, relative chlorophyll index and nitrogen concentrations in leaves, and the grain yield of arabica coffee (Coffea arabica) fertilized with rates of $\mathrm{N}$ as coated and conventional urea, in a sandy soil under rainfed conditions. The experiment was carried out over three crop years, using 'Mundo Novo IAC 388-17-1' coffee, in a randomized complete block design, in a $3 \times 2+1$ factorial arrangement, with three treatments with 150,300 , and $600 \mathrm{~kg} \mathrm{ha}^{-1} \mathrm{~N}$, as coated and conventional urea, and a control without $\mathrm{N}$, with six replicates. Nitrogen increased stem diameter, plant height, $\mathrm{N}$ concentrations and relative chlorophyll index in the leaves, as well as grain yield. Over the three crop years, the highest $\mathrm{N}$ rate provided the greatest grain yield. Coated urea has no advantage over the conventional one, in supplying $\mathrm{N}$ to arabica coffee crop, in sandy soil under rainfed conditions.
\end{abstract}

Index terms: Coffea arabica, grain yield, mineral nutrition, nitrogen, slow release.

\section{Resposta do cafeeiro arábica a doses de ureia revestida e convencional em solo arenoso}

Resumo - O objetivo deste trabalho foi avaliar o crescimento, o índice relativo de clorofila e o teor de $\mathrm{N}$ nas folhas, e a produtividade de grãos do cafeeiro arábica (Coffea arabica) adubado com doses de $\mathrm{N}$ nas formas de ureia revestida e convencional, em solo arenoso em condição de sequeiro. $\mathrm{O}$ experimento foi realizado por três anos agrícolas, com o café 'Mundo Novo IAC 388-17-1', em delineamento de blocos ao acaso, em arranjo fatorial $3 \times 2+1$, com três tratamentos com $150,300,600 \mathrm{~kg} \mathrm{ha}^{-1} \mathrm{de} \mathrm{N}$, como ureia revestida e convencional, e um controle sem aplicação de $\mathrm{N}$, com seis repetições. A adubação nitrogenada aumentou o diâmetro do caule, a altura de planta, os teores de $\mathrm{N}$ e o índice relativo de clorofila nas folhas, assim como a produtividade de grãos. Nos três anos agrícolas, a maior dose de $\mathrm{N}$ proporcionou a maior produtividade de grãos. A ureia revestida não apresenta vantagem, em comparação à ureia convencional, quanto ao fornecimento de $\mathrm{N}$ para a cultura do café arábica, em solo arenoso em condições de sequeiro.

Termos para indexação: Coffea arabica, produtividade de grãos, nutrição mineral, nitrogênio, liberação lenta.

\section{Introduction}

Brazil is the world's largest coffee producer (FAO, 2018), with a cultivated area of more than 2.0 million ha, out of which more than 1.7 
million ha are occupied by arabica coffee (Coffea arabica L.) species (Acompanhamento..., 2019).

Nitrogen $(N)$ is the nutrient that is required in the greatest quantity by arabica coffee, and it limits plant development and yield more than other nutrients (Catani et al., 1965; Raij et al., 1996; Quintela et al., 2011; Lima et al., 2016). The main N source used in Brazil is urea, with an annual consumption of approximately 5.6 million tonnes (IPNI, 2016). Urea has the advantages of higher-N concentrations and solubility, lower corrosivity and cost, and easier handling and application, in comparison to other $\mathrm{N}$ fertilizers (Ruark et al., 2018). However, although coffee plants can uptake volatilized ammonia $\left(\mathrm{N}-\mathrm{NH}_{3}\right)$ through their leaves (Fenilli et al., 2007), volatilization losses can be considerable, especially when urea is applied to the soil surface and under inappropriate climatic conditions (Dominghetti et al., 2016; Souza et al., 2018). Thus, one of the numerous challenges in $\mathrm{N}$-fertilizer research is the development of technologies to minimize $\mathrm{N}$ losses, and increase the $\mathrm{N}$-use efficiency (NUE) (Guelfi, 2017).

Urea coated with polymer-based products that have a high density of electric charges aims to protect urea granules and can promote a gradual release of $\mathrm{N}$, decreasing losses and improving NUE (Reis Junior, 2007; Lorensini et al., 2012; Dominghetti et al., 2016; Lima et al., 2016; Ruark et al., 2018). According to Cahill et al. (2010), a polymer with a high density of charges creates an active shell around the fertilizer, with the negative charges of the polymer sequestering the positively charged ions bound to the enzyme urease that, in turn, decreases the loss of $\mathrm{N}$ by volatilization. Lorensini et al. (2012) found that the application of polymer-coated urea showed the smallest ammonia losses by volatilization, and suggested that it may improve NUE by grapevines (Vitis vinifera L.).

In a one-year experiment, Fernandes \& Fraga Junior (2010) verified that the performance of coated urea (KimCoat), when applied to the soil surface in the spring/summer season was superior to conventional urea; they also observed that coated urea at 210 and $300 \mathrm{~kg} \mathrm{ha}^{-1} \mathrm{~N}$ increased the grain yield of a sprinklerirrigated arabica coffee crop. However, because of the biennial reproductive cycle of arabica coffee plant, the fertilizer applications from November 2007 to March 2008 interfered probably only with the fruit formation and filling, but did not affect the precursor bud formation (Fernandes \& Fraga Junior, 2010). Dominghetti et al. (2016) found greater $\mathrm{NH}_{3}-\mathrm{N}$ loss by volatilization with the use of urea coated with anionic polymers than with the use of conventional urea, in a rainfed coffee crop. In a four-year experiment with drip-irrigation, Lima et al. (2016) found a similar effect of coated and conventional urea on arabica coffee yield. To Dominghetti et al. (2016), the anionic polymers of urea coating were ineffective at retaining $\mathrm{NH}_{4}{ }^{+}$in their negative charges, so the authors suggested that coffee growers should be aware of the characteristics of each technology and its efficacy before use.

The results of the use of coated urea are still inconsistent and inconclusive, although showing potential (Fernandes \& Fraga Junior, 2010; Lorensini et al., 2012; Martins et al. 2014; Ruark et al., 2018). This inconstancy may be mainly related to the climatic conditions, soil types, and the nature of the coating (Cahill et al. 2010; Fernandes \& Fraga Junior, 2010; Dominghetti et al., 2016; Lima et al., 2016). Further studies are needed to compare the $\mathrm{N}$-fertilizer efficiency with that of conventional fertilizers at various $\mathrm{N}$-application rates according to Ruark et al. (2018). In addition, multi-year studies on the use of coated urea in growing coffee in Brazil are still scarce, as the volume of experimental data is still insufficient to determine in which situations this technology is efficient and feasible to be recommended for farmers. Thus, there is no consensus as to advantages on the use of different rates of coated urea rather than the conventional one to supply $\mathrm{N}$ for arabica coffee crop.

The objective of this work was to evaluate the growth, relative chlorophyll index and nitrogen concentrations in leaves, and the grain yield of arabica coffee fertilized with rates of $\mathrm{N}$ as coated and conventional urea, in a sandy soil under rainfed conditions.

\section{Materials and Methods}

The experiment was carried out from October 2014 to June 2017 in a 3.77 ha area, in Sítio Tibiriçá, in the municipality of Bauru, in the state of São Paulo, Brazil $\left(22^{\circ} 14^{\prime} \mathrm{S}, 49^{\circ} 11^{\prime} \mathrm{W}\right.$, at $576 \mathrm{~m}$ altitude). According to the Köppen-Geiger's classification, the predominant climate in the region is subtropical Cfa characterized by dry season and hot summer (Alvares et al., 2013). The annual temperature average is $22.7^{\circ} \mathrm{C}$ (in the last 18 years), and the annual rainfall is $1,290 \mathrm{~mm}$. The climatic

Pesq. agropec. bras., Brasília, v.54, e00767, 2019

DOI: 10.1590/S1678-3921.pab2019.v54.00767 
data during the experimental period are described according to Instituto de Pesquisas Meteorológicas (IPMET, 2019) (Table 1).

The soil of the site is a Latossolo Vermelho-Amarelo distrófico arenoso (Santos et al., 2013), i.e., a Typic Haplustox, with chemical and granulometric characteristics under canopy projection described as follows. At $0-20 \mathrm{~cm}$ soil depths: $9 \mathrm{~g} \mathrm{dm}^{-3}$ organic

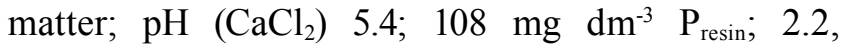
22.0, 10.0, and $17.0 \mathrm{mmol}_{\mathrm{c}} \mathrm{dm}^{-3} \mathrm{~K}, \mathrm{Ca}, \mathrm{Mg}$, and $\mathrm{H}+\mathrm{Al}$, respectively; $22 \mathrm{mg} \mathrm{dm}^{-3} \mathrm{SO}_{4}-\mathrm{S} ; 68 \%$ base saturation (BS); $960 \mathrm{~g} \mathrm{~kg}^{-1}$ sand; $10 \mathrm{~g} \mathrm{~kg}^{-1}$ silt; and $3 \mathrm{~g} \mathrm{~kg}^{-1}$ clay. At $20-40 \mathrm{~cm}$ soil depths: $6 \mathrm{~g} \mathrm{dm}^{-3}$ organic matter; $\mathrm{pH}\left(\mathrm{CaCl}_{2}\right) 4.6 ; 100 \mathrm{mg} \mathrm{dm}^{-3} \mathrm{P}_{\text {resin }} ; 2.3$, 12.0, 4.0, and $21.0 \mathrm{mmol}_{\mathrm{c}} \mathrm{dm}^{-3} \mathrm{~K}, \mathrm{Ca}, \mathrm{Mg}$, and $\mathrm{H}+$ $\mathrm{Al}$, respectively; $42 \mathrm{mg} \mathrm{dm}^{-3} \mathrm{SO}_{4}-\mathrm{S} ; 47 \% \mathrm{BS} ; 92 \mathrm{~g} \mathrm{~kg}^{-1}$ sand; $2 \mathrm{~g} \mathrm{~kg}^{-1}$ silt; and $6 \mathrm{~g} \mathrm{~kg}^{-1}$ clay.

Prior to coffee planting the land was used as pasture with Urochloa decumbens (Stapf) R.D.Webster. Coffee 'Mundo Novo IAC 388-17-1' (Coffea arabica) was planted in December 2010, at 4.0x0.80 m spacing.

The experiment was conducted in a randomized complete block design, in a $3 \times 2+1$ factorial arrangement, with seven treatments and six replicates. The treatments consisted of $\mathrm{N}$ rates $(150,300$, and $\left.600 \mathrm{~kg} \mathrm{ha}^{-1} \mathrm{~N}\right)$, conventional urea $(45 \% \mathrm{~N})$ and coated urea $(43 \% \mathrm{~N})$ as $\mathrm{N}$ sources, and a control without $\mathrm{N}$ fertilization. Coated urea (KimCoat N, Kimberlit, Olímpia, SP, Brazil) granules contained three layers of a high-density charge polymer (that is, partial calcium salt of maleic-itaconic copolymer (NutriSphere-N). Each plot contained seven consecutive plants in one row, totaling $22.4 \mathrm{~m}^{2}$. All plots were arranged consecutively in the same row of crop plants. In each crop year (2014/2015, 2015/2016, and 2016/2017), the fertilizers were applied manually in the projection range of the plant canopy, without incorporation, and split into three applications with 45-day-interval between October and March.

Before the implementation of the experiment, fertilizer applications were performed according to recommendations of Raij et al. (1997), and considering the expected hulled-grain yield of $1,200-1,800 \mathrm{Mg} \mathrm{ha}^{-1}$ in the third year. From the beginning of the experiment, all fertilizer applications were calculated following the recommendations for the expected hulled-grain yield range of 2,400-3,600 $\mathrm{kg} \mathrm{ha}^{-1}$ (Raij et al., 1997). In addition to the treatments, $200 \mathrm{~kg} \mathrm{ha}^{-1}$ per year of $\mathrm{K}_{2} \mathrm{O}$ and $80 \mathrm{~kg} \mathrm{ha}^{-1}$ per year of $\mathrm{P}_{2} \mathrm{O}_{5}$ were also applied to all plots. In January and March of each crop year, magnesium sulfate $\left(2 \mathrm{~kg} \mathrm{ha}^{-1}\right)$, boric acid $\left(1.5 \mathrm{~kg} \mathrm{ha}^{-1}\right)$, manganese sulfate $\left(2 \mathrm{~kg} \mathrm{ha}^{-1}\right)$, zinc (2 $\left.\mathrm{kg} \mathrm{ha} \mathrm{a}^{-1}\right)$, and copper sulfate ( $\left.\mathrm{kg} \mathrm{ha}^{-1}\right)$ were sprayed on coffee leaves. Weed control was performed using mechanized cutting between rows, and through the application of the herbicide glyphosate (720 g a.i. ha-1) in a $1.5 \mathrm{~m}$ strip on each side of the coffee row. Pest and disease managements were conducted by applying

Table 1. Mean monthly temperature and monthly rainfall, from January 2014 to December 2017, in the municipality of Bauru, in the state of São Paulo, Brazil.

\begin{tabular}{|c|c|c|c|c|c|c|c|c|}
\hline \multirow[t]{2}{*}{ Month } & \multicolumn{4}{|c|}{ Mean temperature $\left({ }^{\circ} \mathrm{C}\right)$} & \multicolumn{4}{|c|}{ Rainfall (mm) } \\
\hline & 2014 & 2015 & 2016 & 2017 & 2014 & 2015 & 2016 & 2017 \\
\hline January & 26.3 & 27.5 & 26.1 & 25.0 & 104.6 & 182.4 & 380.2 & 462.0 \\
\hline February & 26.0 & 25.5 & 27.5 & 26.2 & 132.3 & 134.1 & 351.3 & 137.9 \\
\hline March & 24.7 & 24.5 & 25.1 & 24.8 & 125.5 & 251.5 & 118.9 & 135.9 \\
\hline April & 23.2 & 23.7 & 25.2 & 22.6 & 74.4 & 46.7 & 37.8 & 119.1 \\
\hline May & 20.5 & 20.9 & 19.7 & 21.0 & 63.8 & 125.2 & 110.2 & 218.7 \\
\hline June & 20.3 & 20.7 & 18.1 & 19.2 & 0.5 & 0.0 & 94.0 & 22.4 \\
\hline July & 18.9 & 20.3 & 19.5 & 18.5 & 30.5 & 88.1 & 9.1 & 0.0 \\
\hline August & 21.7 & 22.5 & 20.7 & 20.3 & 22.4 & 21.6 & 61.7 & 66.3 \\
\hline September & 23.1 & 24.1 & 21.3 & 24.1 & 125.0 & 220.2 & 24.6 & 16.5 \\
\hline October & 25.0 & 25.3 & 23.3 & 23.9 & 37.3 & 123.4 & 103.6 & 117.9 \\
\hline November & 24.8 & 25.0 & 23.8 & 23.4 & 116.0 & 260.1 & 91.2 & 263.4 \\
\hline December & 25.1 & 25.9 & 25.0 & 25.2 & 257.0 & 259.8 & 143.8 & 95.0 \\
\hline
\end{tabular}


insecticide, the fungicide thiamethoxam (300 $\mathrm{g} \mathrm{ha}^{-1}$ a.i.) + cyproconazole ( $300 \mathrm{~g} \mathrm{ha}^{-1}$ a.i.) to the soil, and foliar sprays of the fungicides tebuconazole (200 $\mathrm{g} \mathrm{ha}^{-1}$ a.i.), pyraclostrobin + epoxiconazole ( $274.5 \mathrm{~g} \mathrm{ha}^{-1}$ a.i.), and copper oxychloride (2.5 $\mathrm{kg} \mathrm{ha}^{-1}$ a.i.). The coffee crop was grown under rainfed conditions.

Before the beginning of the treatments (October 2014), in all plots, coffee plants were measured for stem diameter at $0.05 \mathrm{~m}$ height relatively to soil surface, and for plant height from the soil surface to the plant apex. The average values of stem diameter and plant height were $43.6 \mathrm{~mm}$ and $2.01 \mathrm{~m}$, respectively, and there was no significant difference between the plots. In March of each year, the measurements of stem diameter and plant height were performed. In March and October of 2015 and 2016, and in March 2017, the chlorophyll relative indexes and $\mathrm{N}$ concentrations in the leaves were evaluated. Readings were performed using a chlorophyll meter SPAD 502 (Konica Minolta, Chiyoda, Japan) in five leaves of the third pair of the fructiferous branches, in the middle third of each of the three central plants of each plot (Raij et al., 1997). Two measurements were taken at approximately 12:00 $\mathrm{h}$ per leaf, totaling 30 measurements per plot. Fifteen leaves were collected of each plot, used for the readings with the chlorophyll meter, and subjected to rapid rinsing with water; these samples were then placed in an oven for drying with forced-air circulation at $65^{\circ} \mathrm{C}$ for 72 hours, and ground in a Willey type mill. The ground material was analyzed to determine the $\mathrm{N}$ concentration (Malavolta et al., 1997). To determine the grain yield, fruit from seven plants of each plot were harvested. After the harvest, the coffee cherries were dried on a masonry patio until moisture content between 11 and 12\% was reached. Next, the dried fruit were processed (removal of the hull).

The data were subjected to analyses of variance using the statistical program Sisvar. Means of sources in the factorial arrangement were compared by the $\mathrm{F}$ test, at $5 \%$ probability. The effects of the $\mathrm{N}$ rates were evaluated by a regression analysis, and for this purpose, the control (no $\mathrm{N}$ application) was considered as a zero rate.

\section{Results and Discussion}

Basal stem diameter and plant height were influenced by $\mathrm{N}$ rates (Table 2). Nitrogen fertilization - up to rates from 374 to $493 \mathrm{~kg} \mathrm{ha}^{-1} \mathrm{~N}$ - quadratically increased the stem diameter and plant height of the coffee crop every year. Because $\mathrm{N}$ is required in a greater quantity and is the most limiting nutrient to the growth and development of coffee plants, an adequate $\mathrm{N}$ supply translates into well-known effects on plant mass and crop productivity (Raij et al., 1996; Reis et al., 2009; Quintela et al., 2011), as verified in the first evaluation

Table 2. Stem diameter and plant height of arabica coffee (Coffea arabica) as affected by sources and rates of $\mathrm{N}$ in three crop years ${ }^{(1)}$.

\begin{tabular}{|c|c|c|c|c|c|c|}
\hline \multirow{2}{*}{ Treatment } & \multicolumn{3}{|c|}{ Stem diameter $(\mathrm{mm})$} & \multicolumn{3}{|c|}{ Plant height (m) } \\
\hline & Mar./2015 & Mar./2016 & Mar./2017 & Mar./2015 & Mar./2016 & Mar./2017 \\
\hline \multicolumn{7}{|l|}{$\mathrm{N}$ source } \\
\hline Conventional urea & $55.0 \mathrm{a}$ & $67.3 \mathrm{a}$ & $76.2 \mathrm{a}$ & $2.17 \mathrm{a}$ & $2.55 \mathrm{a}$ & $2.80 \mathrm{a}$ \\
\hline Coated urea & $53.6 \mathrm{a}$ & $66.0 \mathrm{a}$ & $74.6 \mathrm{a}$ & $2.13 \mathrm{a}$ & $2.51 \mathrm{a}$ & $2.80 \mathrm{a}$ \\
\hline \multicolumn{7}{|l|}{$\mathrm{N}$ rate $\left(\mathrm{kg} \mathrm{ha}^{-1}\right)$} \\
\hline 0 & 49.3 & 58.7 & 64.5 & 2.03 & 2.39 & 2.64 \\
\hline 150 & 53.7 & 65.3 & 74.2 & 2.12 & 2.50 & 2.77 \\
\hline 300 & 55.1 & 66.3 & 75.0 & 2.17 & 2.56 & 2.81 \\
\hline 600 & 54.1 & 68.4 & 76.9 & 2.17 & 2.54 & 2.77 \\
\hline Regression & (2) & (3) & (4) & (5) & (6) & (7) \\
\hline Source $\times$ Rate interaction ${ }^{(8)}$ & 0.798 & 0.231 & 0.741 & 0.550 & 0.951 & 0.863 \\
\hline Coefficient of variation $(\%)$ & 6.7 & 5.5 & 6.2 & 4.9 & 4.1 & 4.9 \\
\hline
\end{tabular}

Pesq. agropec. bras., Brasília, v.54, e00767, 2019

DOI: 10.1590/S1678-3921.pab2019.v54.00767 
of the present study. However, the stem diameter and plant height were not influenced by the $\mathrm{N}$ sources tested. Coated urea was not considered superior to conventional urea in providing greater numbers of nodes and length of the plagiotropic branches of irrigated coffee plants (Fernandes \& Fraga Junior, 2010; and Lima et al., 2016), although the studies of these authors have been conducted under irrigation, with irrigation or rain occurring soon after the application of the $\mathrm{N}$ fertilizers. Even without the use of controlled irrigation, a similar situation also occurred in the experiment of the present report, since all the fertilizer applications were followed by almost $30 \mathrm{~mm}$ of precipitation, except for the fertilizer application carried out in October 2014, when precipitation for the whole month was only $37.3 \mathrm{~mm}$ (Table 1 ).

The effectiveness of a coated fertilizer depends on the solubility of granules and the rate of hydrolysis, which regulate the process of nutrient release (Dominghetti et al., 2016; Ruark et al., 2018).
Lara Cabezas et al. (1997) showed that if water is sufficient to dilute the concentration of hydroxyls $\left(\mathrm{OH}^{-}\right)$produced in the hydrolysis reaction around urea granules, and to "incorporate" urea into the soil, there is a decreased ammonia volatilization. Moreover, according to Silva et al. (1995), occurs an increase of the contact between fertilizer and soil particles, which causes the increase of $\mathrm{NH}_{4}{ }^{+}$adsorption into the negative loads of the soil, making it difficult to transform to $\mathrm{NH}_{3}$, leading to $\mathrm{N}$ lost by volatilization. Thus, precipitation occurring shortly after fertilizer application probably reduced the volatilization of $\mathrm{N}$, including conventional urea (Dominghetti et al., 2016; Souza et al., 2018), making $\mathrm{N}$ availability to coffee trees similar in both sources (Table 1).

Nitrogen concentrations and relative chlorophyll indexes in the leaves were positively influenced by $\mathrm{N}$ rates at all times of evaluation (Table 3 ). In all the evaluation times, $\mathrm{N}$ concentrations in the leaves of plants that did not receive $\mathrm{N}$ fertilizer were below the

Table 3. Nitrogen concentration and relative chlorophyll index in the leaves of arabica coffee (Coffea arabica) affected by sources and rates of $\mathrm{N}$, in three crop years ${ }^{(1)}$.

\begin{tabular}{|c|c|c|c|c|c|}
\hline \multirow[t]{2}{*}{ Treatment } & \multicolumn{5}{|c|}{$\mathrm{N}$ concentration $\left(\mathrm{g} \mathrm{kg}^{-1}\right)$} \\
\hline & Mar./2015 & Oct./2015 & Mar./2016 & Oct./2016 & Mar./2017 \\
\hline \multicolumn{6}{|l|}{ N source } \\
\hline Conventional urea & $24.6 \mathrm{a}$ & $27.6 \mathrm{a}$ & $27.6 \mathrm{~b}$ & $25.0 \mathrm{a}$ & $26.2 \mathrm{a}$ \\
\hline Coated urea & $25.7 \mathrm{a}$ & $27.5 \mathrm{a}$ & $28.6 \mathrm{a}$ & $25.0 \mathrm{a}$ & $26.2 \mathrm{a}$ \\
\hline \multicolumn{6}{|l|}{$\mathrm{N}$ rate $\left(\mathrm{kg} \mathrm{ha}^{-1}\right)$} \\
\hline 0 & 18.7 & 24.9 & 21.0 & 21.0 & 19.3 \\
\hline 150 & 22.7 & 27.7 & 26.7 & 22.8 & 25.6 \\
\hline 300 & 25.5 & 27.0 & 27.5 & 24.7 & 26.7 \\
\hline 600 & 27.3 & 27.8 & 30.2 & 27.5 & 27.0 \\
\hline Regression & (2) & (3) & (4) & (5) & (6) \\
\hline Source $\times$ Rate interaction ${ }^{(7)}$ & 0.085 & 0.193 & 0.730 & 0.151 & 0.782 \\
\hline Coefficient of variation (\%) & 5.5 & 8.0 & 6.0 & 6.6 & 6.7 \\
\hline $\mathrm{N}$ source & \multicolumn{5}{|c|}{ Relative chlorophyll index (SPAD) } \\
\hline Conventional urea & $58.2 \mathrm{~b}$ & $58.5 \mathrm{a}$ & $56.1 \mathrm{a}$ & $49.1 \mathrm{a}$ & $54.9 \mathrm{a}$ \\
\hline Coated urea & $59.6 \mathrm{a}$ & $59.3 \mathrm{a}$ & $57.3 \mathrm{a}$ & $50.2 \mathrm{a}$ & $56.0 \mathrm{a}$ \\
\hline \multicolumn{6}{|l|}{$\mathrm{N}$ rate $\left(\mathrm{kg} \mathrm{ha}^{-1}\right)$} \\
\hline 0 & 45.3 & 50.9 & 41.5 & 40.9 & 38.0 \\
\hline 150 & 55.9 & 55.8 & 50.3 & 45.1 & 53.8 \\
\hline 300 & 60.2 & 58.8 & 57.8 & 49.2 & 55.5 \\
\hline 600 & 60.6 & 62.1 & 62.0 & 54.6 & 57.0 \\
\hline Regression & (8) & (9) & (10) & (11) & (12) \\
\hline Source $\times$ Rate interaction ${ }^{(7)}$ & 0.542 & 0.875 & 0.757 & 0.519 & 0.445 \\
\hline Coefficient of variation (\%) & 4.1 & 6.3 & 7.3 & 5.4 & 7.7 \\
\hline \multicolumn{6}{|c|}{ 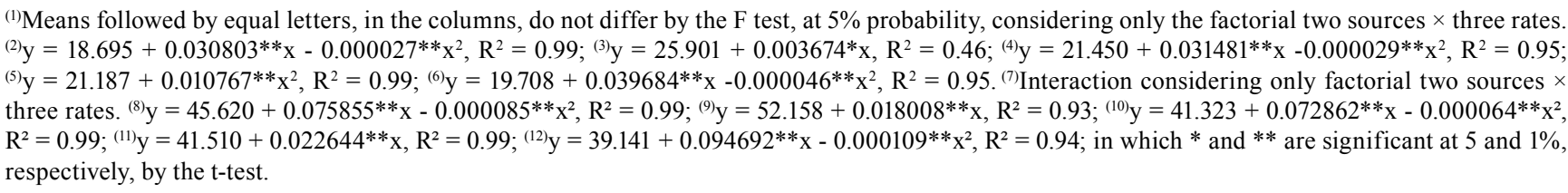 } \\
\hline
\end{tabular}


range considered suitable for the coffee crop, which is from 26 to $32 \mathrm{~g} \mathrm{~kg}^{-1}$ (Raij et al., 1997). In the evaluations of March 2015 and October 2016, only the treatment with the highest- $\mathrm{N}$ rate $\left(600 \mathrm{~kg} \mathrm{ha}^{-1}\right)$ provided an $\mathrm{N}$ concentration within the appropriate range, while in the other evaluation periods, plants of all treatments that received $\mathrm{N}$ had adequate nutrient content. Plants that showed lower-N concentrations had also lowerrelative chlorophyll indexes (Table 3 ). Nitrogen is a mobile element in the phloem, and when $\mathrm{N}$ deficiency occurs, the older leaves begin to lose their intense green color, changing to a light green color, which slowly is replaced by chlorosis of the vegetative part, a situation verified in the control treatment and in the treatments with $150 \mathrm{~kg} \mathrm{ha}^{-1} \mathrm{~N}$, in the years with a greater load.

Regardless of the rate used, coated urea was superior to conventional urea for leaf-N concentrations, in March 2016, and for relative chlorophyll index, in March 2015 (Table 3). Although these differences may indicate a relative superiority, under certain conditions, there was no interaction between the studied factors, showing that under the conditions of the present study, the polymer-coated urea had little effect on increasing the $\mathrm{N}$ uptake to the coffee crop, in comparison to conventional urea.
There were interaction effects of source $\times \mathrm{N}$ rate on hulled-grain yield in the 2014/2015 crop year, and effects of $\mathrm{N}$ rates in the 2015/2016, 2016/2017, and on the average of three years (Table 4). In 2014/2015, grain yield increased linearly with the $\mathrm{N}$ rates only when coated urea was used, and there was no effect of conventional urea. However, at $150 \mathrm{~kg} \mathrm{ha}^{-1} \mathrm{~N}$, coated urea promoted a lower-hulled-grain yield than the conventional urea, with no differences between the sources at the higher- $\mathrm{N}$ rates. The urea coating may have limited the availability of $\mathrm{N}$ to plants at the required time, as for developing and filling fruits, especially considering the lower-rainfall volumes recorded in October and November 2014, and January 2015 (Table 1). In a sprinkler-irrigated coffee crop in the municipality of Uberaba, in the state of Minas Gerais, Brazil, Fernandes \& Fraga Junior (2010) found a higher-grain yield when they used coated urea than that using conventional urea, but only at $\mathrm{N}$ rates higher than $150 \mathrm{~kg} \mathrm{ha}^{-1}$. By these results, it can be said that the use of coated fertilizer may not be a viable alternative in certain situations with low-water availability. Lima et al. (2016) studied the application of coated and conventional urea at 210 and $300 \mathrm{~kg} \mathrm{ha}^{-1}$ $\mathrm{N}$, respectively, in irrigated coffee in the municipality of Araguari, in the state of Minas Gerais, Brazil, and

Table 4. Hulled-grain yield of arabica coffee (Coffea arabica) affected by sources and rates of N, in three crop years ${ }^{(1)}$.

\begin{tabular}{|c|c|c|c|c|c|}
\hline \multirow[t]{3}{*}{ Treatment } & \multicolumn{5}{|c|}{ Hulled-grain yield $\left(\mathrm{kg} \mathrm{ha}^{-1}\right)$} \\
\hline & \multicolumn{2}{|c|}{$2014 / 2015$ crop year } & \multirow{2}{*}{$\begin{array}{l}2015 / 2016 \\
\text { crop year }\end{array}$} & \multirow{2}{*}{$\begin{array}{c}2016 / 2017 \\
\text { crop year }\end{array}$} & \multirow{2}{*}{$\begin{array}{c}\text { Average } \\
\text { (3 crop years) }\end{array}$} \\
\hline & Conventional urea & Coated urea & & & \\
\hline \multicolumn{6}{|l|}{$\mathrm{N}$ source } \\
\hline Conventional urea & - & - & $3,276 \mathrm{a}$ & $2,467 \mathrm{a}$ & $2,147 \mathrm{a}$ \\
\hline Coated urea & - & - & $3,306 a$ & $2,444 a$ & $2,158 \mathrm{a}$ \\
\hline \multicolumn{6}{|l|}{$\mathrm{N}$ rate $\left(\mathrm{kg} \mathrm{ha}^{-1}\right)$} \\
\hline 0 & \multicolumn{2}{|c|}{621} & 1,308 & 1,290 & 1,073 \\
\hline 150 & $775 \mathrm{~A}$ & $533 \mathrm{~B}$ & 2,567 & 2,007 & 1,743 \\
\hline 300 & $687 \mathrm{~A}$ & $711 \mathrm{~A}$ & 3,414 & 2,162 & 2,092 \\
\hline 600 & $729 \mathrm{~A}$ & $829 \mathrm{~A}$ & 3,892 & 3,197 & 2,623 \\
\hline Regression & ns & (2) & (3) & (4) & (5) \\
\hline Source $\times$ Rate interaction ${ }^{(6)}$ & \multicolumn{2}{|c|}{$<0.001$} & 0.913 & 0.419 & 0.149 \\
\hline Coefficient of variation (\%) & \multicolumn{2}{|c|}{14.9} & 12.0 & 14.3 & 8.1 \\
\hline \multicolumn{6}{|c|}{$\begin{array}{l}\text { (1) Means followed by equal letters, uppercase in the rows in the } 2014 / 2015 \text { crop year, and lowercase in the columns in the other years and on the average } \\
\text { of three crop years, do not differ by the } \mathrm{F} \text { test, at } 5 \% \text { probability, considering only the factorial two sources } \times \text { three rates. }{ }^{(2)} \mathrm{y}=562.3+0.4246^{* *} \mathrm{x} \text {, } \\
\mathrm{R}^{2}=0.74 ;{ }^{(3)} \mathrm{y}=1308.296+9.741044^{* *} \mathrm{x}-0.009060^{* *} \mathrm{x}^{2}, \mathrm{R}^{2}=0.99 ;(4) \mathrm{y}=1369.486+3.026328^{* *} \mathrm{x}, \mathrm{R}^{2}=0.97 ;{ }^{(5)} \mathrm{y}=1094.593+4.401412^{* *} \mathrm{x}-0.003111^{* * *} \mathrm{x}^{2} \text {, } \\
\mathrm{R}^{2}=0.99 \text {; in which } * \text { and } * * \text { are significant by the t-test, at } 5 \text { and } 1 \% \text { probabilities, respectively. }{ }^{\mathrm{n}} \text { Nonsignificant. }{ }^{(6)} \text { Interaction considering only the } \\
\text { factorial two sources } \times \text { three rates. }\end{array}$} \\
\hline
\end{tabular}


did not also observe differences in grain yield of the plants fertilized with the different $\mathrm{N}$ sources. It is important to point out that the grain yield evaluated in $2015(2014 / 2015)$ was influenced by the fertilizer application in the 2013/2014 crop season, which was carried out equally in all plots, that is, before the beginning of the experiment. Thus, the different fertilizer applications that started in October 2014 did not interfere with the bud formation phase, which gave rise to fruit harvested in 2015, but it did interfere with the formation and filling of fruit, which limited production in all treatments in the first crop year.

In 2015/2016 and on average of three years, regardless of the source used, hulled- grain yield increased due to the application of $\mathrm{N}$ fertilizer up to the estimated rate of $538 \mathrm{~kg} \mathrm{ha}^{-1} \mathrm{~N}$ and the highest-N rate $\left(600 \mathrm{~kg} \mathrm{ha}^{-1}\right)$ studied, respectively (Table 4). In 2016/2017, N rates had a positive linear effect on coffee yield. In a sandy clay loam soil, Fernandes \& Fraga Junior (2010) obtained a coffee grain yield increase up to the highest-N rate (300 $\left.\mathrm{kg} \mathrm{ha}^{-1}\right)$ of both coated and conventional urea, but only up to the $\mathrm{N}$ rate of $200 \mathrm{~kg} \mathrm{ha}^{-1}$ of ammonium nitrate. Quintela et al. (2011) studied N rates applied via fertigation in a five-year-old 'Catuaí Vermelho IAC H2077-2-5-24' plantation in the municipality of Garanhuns, in the state of Pernanbuco, Brazil, and observed that the hulled-grain yield increased up to the estimated rate of $338 \mathrm{~kg} \mathrm{ha}^{-1} \mathrm{~N}$. The differences in the responses found are possibly related, among other factors, to the sandy texture and the low-organic matter content in the soil, which facilitates the $\mathrm{N}$ loss (Guelfi, 2017; Souza et al., 2018), as well as to the rainfall condition, cultivar, and crop age.

At the same time, the use of coated urea provided some positive variation in the $\mathrm{N}$ concentration and the relative chlorophyll index in the leaves (Table 3), but a decreased grain yield also occurred when it was used in a specific situation (Table 4), showing that this technology demands specific knowledge of its "mode of action". Martins et al. (2014) followed the process of dissolving granules of the two types of urea used in the present study and verified, with the help of a stereoscope microscope, that the inner urea of the polymer layers dissolved simultaneously with the conventional urea, from the moment it was placed in contact with water; in less than $5 \mathrm{~min}$, only the empty structure of the polymer layers that coated the urea remained. The authors suggested that this type of coating should protect the fertilizer while it is deposited on the dry surface of the soil, but rain or irrigation, which keeps the soil surface soaked, would allow the rapid solubilization of fertilizers similar to common urea. The results of the present study are indicative that the use of coated urea does not lead to greater responses than the use of conventional urea, when irrigation is available, or when the application coincides with rainy periods, and the study does not show advantages for the use of the coated urea type of fertilizer.

\section{Conclusions}

1. The $\mathrm{N}$ fertilization up to the $600 \mathrm{~kg} \mathrm{ha}^{-1} \mathrm{~N}$ improves the $\mathrm{N}$ nutrition and plant growth of arabica coffee (Coffea arabica) crop, as well as increases hulled-grain yield regardless of the $\mathrm{N}$ source used either coated or conventional urea.

2. The use of polymer-coated urea shows no advantage over that of conventional urea in providing $\mathrm{N}$ for arabica coffee crop in sandy soil, under rainfed conditions.

\section{Acknowledgments}

To Conselho Nacional de Desenvolvimento Científico e Tecnológico ( $\mathrm{CNPq}$ ), for granting an award for excellence in research to the second author, and a scholarship to the fourth author.

\section{References}

ALVARES,C.A.; STAPE,J.L.; SENTELHAS,P.C.;GONÇALVES, J.L.M.; SPAROVEK, G. Köppen's climate classification map for Brazil. Meteorologische Zeitschrift, v.22, p.711-728, 2013. DOI: https://doi.org/10.1127/0941-2948/2013/0507.

CAHILL, S.; OSMOND, D.; WEISZ, R.; HEINIGER, R. Evaluation of alternative nitrogen fertilizers for corn and winter wheat production. Agronomy Journal, v.102, p.1226-1236, 2010. DOI: https://doi.org/10.2134/agronj2010.0095.

CATANI, R.A.; PELEGRINO, D.; BERGAMIN FILHO, H.; GLÓRIA, N.A. da; GRANER, C.A.F. A absorção de nitrogênio, fósforo, potássio, cálcio, magnésio e enxofre pelo cafeeiro: Coffea arabica variedade mundo novo (B. Rodr.) Choussy aos dez anos de idade. Anais da Escola Superior de Agricultura Luiz de Queiroz, v.22, p.81-93, 1965. DOI: https://doi.org/10.1590/S007112761965000100007.

ACOMPANHAMENTO DA SAFRA BRASILEIRA [DE] CAFÉ: safra 2019: segundo levantamento, v.5, n.2, maio 2019. Available 
at: $<$ https://www.conab.gov.br/info-agro/safras/cafe/boletim-dasafra-de-cafe>. Accessed on: July 222019.

DOMINGHETTI, A.W.; GUELFI, D.R.; GUIMARÃES, R.J.; CAPUTO, A.L.C.; SPEHAR, C.R.; FAQUIN, V. Nitrogen loss by volatilization of nitrogen fertilizers applied to coffee orchard. Ciência e Agrotecnologia, v.40, p.73-183, 2016. DOI: https://doi. org/10.1590/1413-70542016402029615.

FAO. Food and Agriculture Organization of the United Nations. Faostat: Food and Agriculture Organization Statistic: Crops 2016. Available at: <http://www.fao.org/faostat/en/\#data/QC $>$. Accessed on: Mar. 262018.

FENILLI, T.A.B.; REICHARDT, K.; TRIVELIN, P.C.O.; FAVARIN, J.L. Volatilization of ammonia derived from fertilizer and its reabsorption by coffee plants. Communication in Soil Science and Plant Analysis. v.38, p.1741-1751, 2007. DOI: https:// doi.org/10.1080/00103620701435514.

FERNANDES, A.L.T.; FRAGA JUNIOR, E.F. Doses de fontes nitrogenadas convencionais e nitrogênio polimerizado na produtividade e maturação do cafeeiro irrigado. FAZU em Revista, n.7, p.37-41, 2010.

GUELFI, D. Fertilizantes nitrogenados estabilizados, de liberação lenta ou controlada. Informações Agronômicas, n.157, p.1-14, 2017.

IPMET. Instituto de Pesquisas Meteorológicas de Bauru-SP. Dados Históricos. Available at: <https://www.ipmet.unesp. br/2estHist.php>. Acessed on: Jan. 252019.

IPNI. International Plant Nutrition Institute. Evolução do consumo aparente de $\mathrm{N}, \mathrm{P}, \mathrm{K}$ e total de NPK no Brasil. Available at: <http://brasil.ipni.net/article/BRS-3132\#aparente>. Acessed on: Mar. 292018.

LARA CABEZAS, W.A.R.; KORNDORFER, G.H.; MOTTA, S.A. Volatilização de $\mathrm{N}-\mathrm{NH}_{3}$ na cultura de milho: I. Efeito da irrigação e substituição parcial da uréia por sulfato de amônio. Revista Brasileira de Ciência do Solo, v.21, p.481-487, 1997. DOI: https://doi.org/10.1590/S0100-06831997000300018.

LIMA, L.C. de; GONÇALVES, A. de C.; FERNANDES, A.L.T.; SILVA, R. de O.; LANA, R.M.Q. Crescimento e produtividade do cafeeiro irrigado, em função de diferentes fontes de nitrogênio. Coffee Science, v.11, p.97-107, 2016.

LORENSINI, F.; CERETTA, C.A.; GIROTTO, E.; CERINI, J.B.; LOURENZI, C.R.; CONTI, L.; TRINDADE, M.M.; MELO, G.W.; BRUNETTO, G. Lixiviação e volatilização de nitrogênio em um Argissolo cultivado com videira submetida à adubação nitrogenada. Ciência Rural, v.42, p.1678-4596, 2012. DOI: https://doi.org/10.1590/S0103-84782012005000038.

MALAVOLTA, E.; VITTI, G.C.; OLIVEIRA, S.A. de. Avaliação do estado nutricional das plantas: princípios e aplicações. 2.ed. Piracicaba: Potafos, 1997. 319p.
MARTINS, I.S.; CAZETTA, J.O.; FUKUDA, A.J.F. Condições, modos de aplicação e doses de ureia revestida por polímeros na cultura do milho. Pesquisa Agropecuária Tropical, v.44, p.271-279, 2014. DOI: https://doi.org/10.1590/S198340632014000300010.

QUINTELA, M.P.; SILVA, T.J.A.; BOMFIM-SILVA, E.M.; SILVA, E.F.F.; BEBÉ, F.V. Parâmetros produtivos e nutricionais do cafeeiro submetido adubação nitrogenada na região de Garanhuns. Revista Caatinga, v.24, p.74-79, 2011.

RAIJ, B. van; CANTARELLA, H.; QUAGGIO, A.J. Estimulantes: café. In: RAIJ, B. van; CANTARELLA, H.; QUAGGIO, J.A.; FURLANI, A.M.C. (Ed.). Recomendações de adubação e calagem para o Estado de São Paulo. 2.ed. rev. e atual. Campinas: Instituto Agronômico, 1997. p.93-104. (IAC. Boletim técnico, 100).

RAIJ, B. van; COSTA, W.M. da; IGUE, T.; SERRA, J.R.M.; GUERREIRO, G. Calagem e adubação nitrogenada e potássica para o cafeeiro. Bragantia, v.55, p.347-355, 1996. DOI: https://doi. org/10.1590/S0006-87051996000200021.

REIS JUNIOR, R. dos A. KimCoat - uma nova ferramenta para otimização do uso de fertilizantes. Informações Agronômicas, n.117, p.13-14, 2007.

REIS, A.R.; FAVARIN, J.L.; GALLO, L.A.; MALAVOLTA, E.; MORAES, M.F.; LAVRES JUNIOR, J. Nitrate reductase and glutamine synthetase activity in coffee leaves during fruit development. Revista Brasileira de Ciência do Solo, v.33, p.315-324, 2009. DOI: https://doi.org/10.1590/S010006832009000200009 .

RUARK, M.D.; SORATTO, R.P.; ROSEN, C.J. Merits and limitations of enhanced efficiency fertilizers. In: LAL, R.; STEWART, B.A. (Ed.). Soil nitrogen uses and environmental impacts. Boca Raton: CRC Press, 2018. p.289-311. (Advances in Soil Science).

SANTOS, H.G. dos; JACOMINE, P.K.T.; ANJOS, L.H.C. dos; OLIVEIRA, V.A. de; LUMBRERAS, J.F.; COELHO, M.R.; ALMEIDA, J.A. de; CUNHA, T.J.F.; OLIVEIRA, J.B. de. Sistema brasileiro de classificação de solos. 3.ed. rev. e ampl. Brasília: Embrapa, 2013. 353p.

SILVA, A.J.; LIMA JÚNIOR, M.A.; FERREIRA, N.C.M.; FRAGA, V.S. Perdas de amônia por volatilização proveniente da uréia aplicada a solos dos trópicos úmidos. Revista Brasileira de Ciência do Solo, v.19, p.141-144, 1995.

SOUZA, J.A.; ROCHA, G.C.; GOMES, M. de P.; REZENDE, C.H.S. Nitrogen dynamics in a Latosol cultivated with coffee. Revista Brasileira de Engenharia Agrícola e Ambiental, v.22, p.390-395, 2018. DOI: https://doi.org/10.1590/1807-1929/agriambi. v22n6p390-395. 